\title{
Views and reviews of microcredit thoughts and MFIs services in the world
}

\section{Rouf, Kazi Abdur $\bowtie$}

York University, Noble International University, Canada (kazirouf@gmail.com)

Research Associate, Center for Learning, Social Economy and Work, University of Toronto

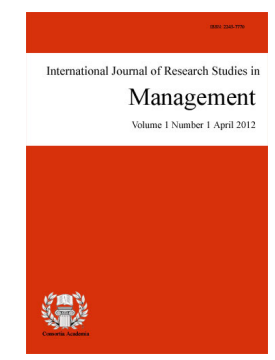

ISSN: $2243-7770$ Online ISSN: 2243-7789

OPEN ACCESS

\section{Abstract}

This paper is critically analyzing books, articles, and case studies of the course materials of the Harvard micro-financing six-week summer training program conducted at the Harvard University in 2005. All the attended trainees of this training program were the executives from different MFIs across the world. This training program orients the trainees to different micro-financing services, thoughts, financial strategies, and policies etc. in the world. The aim of this microfinance analytical paper is to assist readers to get an in-depth idea about microcredit different innovations, thoughts, and practices that are prevailing across the world. Although the attended trainees of the Harvard micro-financing training intensively discuss and identify MFIs problems and challenges that they are facing, very few conversations were made on how to design, develop and improve IT skills of their loan transactions, bookkeeping and monitoring devices that they are suffering from. These IT skills developments are very crucial for MFIs in order to reduce their costs and to efficiently operate their microcredit services to the poor entrepreneurs in the world and to develop their institutional sustainable capacity building.

Keywords: Bank Rakyat Indonesia (BRI); commercialization of micro-financing; citizenry skills development of micro-borrowers; deep poverty; defaulter micro-borrowers; entrepreneurial skills development 


\section{Views and reviews of microcredit thoughts and MFIs services in the world}

\section{Introduction}

The emergence of different NGOs, MFIs, and their services to micro-credit, cooperatives, social businesses, and social enterprises through their policies and activities has a transformation to benefit/wellbeing to disadvantaged people. Many studies find NGOs, and MFIs are the safeguard of social equilibrium in different communities in both developed and developing countries of the world although recent economic growth without people-centered development creates inequalities and socioeconomic divide in different communities. Therefore, NGOs, MFIs, cooperatives and social enterprises existences are crucial and important in the contemporary hegemonic capitalist society as private and public institutions failed to meet and to protect basic human rights of people and to eliminate poverty, although many articles relate microcredit program initiative with neoliberal exploitative negative hegemony.

Nevertheless, microfinance programs target the poor of the community and provide microloan services to the disadvantaged people in the community. Through microfinance services, poor people are not only receive loans for running their small business, but they also develop their savings behaviors and develop their social capital, political capital, cultural capital and even human capital. Many disadvantaged people become empowered socially, economically, politically, and free them from different exploitation and social injustice. However, these organizations and their programs are suffering from resources, and organizational capability building makes them challenging in the hegemonic globalized capitalist society to serve the bottom people.

\section{Harvard micro-financing six-week summer training program}

The Harvard Business School offers international microfinance training every alternative year although recently this training program is closed. My two colleagues; microcredit practitioners, attended this training program in 2005 and in 2008. I collected all scholarly articles that were used in the training program. In addition, I downloaded some more microcredit articles from 'World Development Report' publications, and 'Sage publications'. I collected three books published by Kumarian Press Inc. The books critically analyzed microcredit. The names of the books are 'The Commercialization of Microfinance: Balancing business and development'; 'The new world of microenterprise finance: Building healthy financial institutions for the poor'; and 'Saving services for the poor'. Below is the attempt to review the articles books that were used in the Harvard International Microfinance Training Program and with a goal that the above-mentioned microcredit articles and books could help readers to get an in-depth idea about different microcredit thoughts, innovations, and practices in different countries of the world.

The Harvard micro-financing six-week summer training brings trainees from different MFIs practitioners across the world and orients them to different micro-financing programs, MFIs different mode of operands, different financial strategies and policies and their bookkeeping and monitoring different devices. The purpose of this training program is to share and exchange participated MFI practitioners' operational strategies and exchange views and ideas of different case studies of different MFIs presented in the training. These trainees also discuss how to solve delinquent loan portfolios. There are 32 MFIs representatives participated from across the world in this training program in 2005. All the training participants were executives of the MFIs across the world. They were both from developed and developing countries. The attended trainees themselves were the resource person for this training program because many of them relate their contextual experience in analyzing the course themes and materials from their contextual perspectives. Although there was no field trip arrangement in the program for the participants to visit MFIs for getting practical hands-on experience on good MFIs and struggling MFIs, attended trainees presented their own experiences and challenges they are facing in implementing their micro-financing programs in their communities. 


\section{Issues}

Access to basic financial services such as credit, savings, and insurance is enhancing to develop the entrepreneurial skills and opportunities among those poor who are currently outside the banking services, financial markets, and services. Such access can promote the economic aspirations and empowerment of the poor in their own communities. Although many micro-entrepreneurs have access to microcredit for their business capital; however, many microcredit institutions have been suffering from lack of capital, legal entity, defaulter clients, operational inefficiency, and financial insufficiency. Even though MFIs main functions are for providing credit to disadvantaged micro-entrepreneurs, there are huge expectations raised for micro-borrowers to free them from capitalistic exploitation, liberated them from male chauvinism, free them from men violence, develop their citizenry development, and relief them from social injustice and environmental degradation. Many researchers raise how poor people are suffering from structural adjustment policies (SAP), globalization, consumerism, formal and informal financial market and suffering from multinational corporations' (MNCs) free trade market competitions and exploitation etc. Yes, poor people are suffering from all these social, economic and environmental anomalies; however, their micro-financing agencies are suffering from IT skills development on loan transactions, bookkeeping recording and proper IT monitoring devices. Although this paper raised these important essential points for MFIs, the researcher doesn't examine to these strategic gaps; however, he (writer of this paragraph) will use and relate micro-credit different issues mentioned in the above-stated books and piece of writings' themes in the following narratives.

\section{Views and reviews of microcredit thoughts and case study analysis}

\subsection{History of MFIs and their issues}

Hollis and Sweetman (1998) in their articles Microcredit: What can we learn from the past? Narrate the history of micro-credit institutions started from English lending charities. Hollis and Sweetman (1998) narrate that in Great Britain about 3\% of all charitable donations were set aside for loans to ambitions young men during 1480-1660. Their credit operations interest rates were often zero or interest was paid to a charity. Each year such loans launched about 150 men on careers. But some loans required cosignatories as collections which were difficult. There was also the Irish Loan Funds available through the Irish Reproductive Loan Fund Institution (RLFI) in 1822. In the wake of a famine, it distributed 55,000 pounds to different small towns. Loan money came from altruistic individuals. A central board in Dublin regulated the independent funds and made money by a small charge on each loan fund. Each loan was no more than 10 pounds and repaid over 20 weeks, with an interest rate of $12 \%$. However, the Great Famine of the 1840s caused many funds to shut down, but the surviving ones grew strongly. In the 1880s-1890s profiteers took over the system and started corrupting it, seeking profit. Mismanagement and corruption ultimately failed the project.

There is another micro-credit program in Europe calls German Raiffeisen Credit Cooperatives (GRCC) successfully run in Germany initiated in the 1840s. It has rural unlimited liability cooperative. Now its credit cooperative idea spread throughout the world. Its loans varied from under ten pounds to over 250 pounds. It is successful at avoiding large losses. GRCC members knew borrowers personally and there was a strong incentive to ensure loans were paid. Later Irish Credit Cooperatives modeled on the GRCC. The government had encouraged their activities and provide subsidies. However, this program is unsuccessful at attracting deposits thus results from the unsustainable impact.

Italian Casse Rurali is another replication of German Raiffeisen which is highly successful work in different small towns and villages in Italy. It had raised funds through deposits. However, here members were required to work gratis (free) for the cooperative where many borrowers unwilling to work in the cooperative societies. However, it reduced the cost of borrowing and enable borrowers to retain a surplus. However, members demand instead fix uniform interest rates they demand interest rates should be set locally. The program record shows that 
the more successful sustained organizations made considerable use of volunteers. Later on, this organization got government attention and need to follow government guidelines.

Counts (2008) writes a book called Small Loans, Big Dreams. In this book, Alex Counts describes the origin of Grameen Bank and its objectives. The book has nine borrowers' autobiographies. The author mentions that the rural poor of Bangladesh never received loans from the bank that are desperately in needing credit. They are outside the orbit of the bank loan transaction system in Bangladesh. Muhammed Yunus, professor of Chittagong University Economics department, initiated a microcredit action research program with the help of central bank (Bangladesh Bank) in 1979 with the following objectives: (1) Extend the banking facilities to poor people specially to women and create self-employment opportunities among them, (2) eliminate the exploitation of the moneylenders, (3) promote small businesses among poor women, (4) bring disadvantaged people into organization that can enhance their socio-economic and political strength through mutual support and empower them.

The target of this microcredit pilot action program was to reverse the vicious circle of 'low income, low savings, low investment, low income" into an expanding system of low income, small loans investment, more income, more credit, more investment, more income." In October 1983, the Grameen Bank project transformed to into an independent bank by a Government Ordinance (P.O. \# 127 of 1972). The mission of the bank is to alleviate poverty from the lives of the poor people. Alex Counts was an internee of Grameen Bank stayed in the Kandua Madhupur, Tangail branch in 1987-1988. I was an area manager of the Grameen Bank Madhupur area during that period. He learned Grameen bank group-based micro-financing system staying at the grass root Grameen bank branch. Alex incorporated his hands-on practical experience in his book as an outsider.

White and Campion (2002) in their article Transformation: Journey from NGO to Regulated MFI asserts that many NGO organizations are turning to regulated MFIs for their survival through interest earning income. BancoSol is an example created in Bolivia in 1992; the microfinance industry witnessed the birth of a new trend in institutional development: the transformation of NGOs into regulated financial institutions. The term 'transformation' they have used generically here to reflect the institutional process of change that occurs when microfinance NGOs create or spin-off regulated MFIs (White \& Campion, 2002, p. 20). Here authors provide statistics that of the seven thousand NGOs providing microfinance services, seven are transformed MFIs in the world. Their common objectives are access to commercial capital, the ability to mobilize local savings, improved customer service, and to expanded outreach; however, the problem is this transformation MFI into a formal financial institution is viewed as the means to attain self-sustainability and profitability (White \& Campion, 2002, p. 23) that brings neo-liberal agenda in outreach programs. MFIs are unable to get loan capital funds from the market; however, if get pay high interest that results from charge high-interest rate to their disadvantaged borrowers. Therefore, White and Campion (2002) understand MFIs ally with the private sector for funding cannot bring successful results to date to expand outreach. The article also mentions MFIs some key issues such as (1) integration into the formal financial system that regulated by legislation, (2) can the benefits of transformation be achieved with the current political and economic environment? To solve these issues, Victoria White and Anita Campion suggest for MFIs well-defined mission, own ownership and governance, and Board formation. In practice, it is found that many MFIs have the well-defined mission, and they are running independently; however, many of them have limited outreach to the ultra-poor.

\subsection{SME development through microcredit}

Fischer (1995) in his article The basic problem in financing small businesses talks about the characteristics of small enterprises (SEs) and their benefits in the community. Small enterprises are considered to have an advantage over large-scale establishments because SEs are labor-intensive and use relatively simple techniques of production. They demonstrate a higher degree of efficiency in using capital and in mobilizing savings, entrepreneurial talent and other resources. However, here the problem is macroeconomic policies leading to high and volatile inflation rates have been blamed for discrimination against SEs. 
The article also mentions that small enterprise can best be encouraged by creating a neutral policy environment that is not biased in favor of competing for large-scale investments that minimize institutional constraints. Fischer (1995) says that although macroeconomic stabilization, liberalization, and deregulation of financial markets and structural adjustment remain the most important policy issues. However, much more attention has to be given to hitherto rather neglected policy areas such as strengthening competition in the financial sector as well as removing institutional constraints for the small enterprise sector, including access to markets and information, and regularization of their property rights (Fischer, 1995, p. 23). However, state emphasizes even invites to corporate businesses and provides subsidy or tax exemptions to corporations to set up their business in the country. This step is anti to rural finance and small businesses that are flourishing in Bangladesh although the current government of Bangladesh emphasizes on rural and agricultural financing in order to flourish agri-businesses and small business in Bangladesh.

SMEs, Growth, and Poverty: Cross-Country Evidence article written by Beck, Demirguc-Kunt, and Levine (2005) talk about pros and cons of small, medium enterprise (SME) development with a specific reference to the World Bank SME study conducted by Levine and Renelt (1992). To accelerate growth and reduce poverty, the World Bank Group and other international aid agencies provide targeted assistance to small and medium-sized enterprises (SMEs) in developing economies (Beck et al., 2005, p. 199). According to them, the pro-SME policy is based on three core arguments: First SMEs enhance competition and entrepreneurship and hence have external benefits on economy-wide efficiency, innovation, and aggregate productivity growth. Therefore, direct government support of SMEs can help countries exploit the social benefits from greater competition and entrepreneurship (Beck et al., 2005, p. 200). Finally, SME expansion boosts employment more than large firm growth because SMEs are more labor intensive. From this perspective subsidizing SMEs represent a poverty elevation tool (Beck et al., 2005, p. 200).

However, some authors have skeptical views stress the advantages of large firms and challenge the assumptions underlying the pro-SME view. Larger firms are more stable with higher quality jobs. Some countries are better suited for the type of work undertaken by large firms, for example, USA, and Canada. However, Beck, Kunt, and Levine (1992) make cross-country regression studies done on the links between SMEs and economic growth and poverty alleviation yield different results- (1) there is a robust, positive relationship between the relative size of the SME sector and economic growth (Beck et al., 2005, p. 201). However, the study did not find a significant relationship between SMEs and poverty alleviation. Therefore, Beck et al., 2005) concluded, "We do not find that SMEs exert a differential impact on the poor" (Ibid., 2005, p. 202). However, these contradictory studies are country-specific and involve only a few countries; however, maximum countries get benefits of microeconomics from SME (Ibid., 2005, p. 2002).

\subsection{Commercialization of microcredit and sustainability of microcredit program}

Michael Chu (2007) in his paper Commercial returns at the base of the Pyramid narrates elements of benefits of legitimate commercial microfinance market as well as microfinance as a separate commercial segment. Chu (2007) talks although the study of microfinance activities have been centered on the poor, MFIs should be able to generate revenue stream sufficient to cover all their expense and yield a surplus. He emphasizes on MFIs profitability needs to be sustained and the activity must generate financial returns at least equal to the average of those with similar risk profiles in order to remain sustainable. Therefore, MFIs access to bond markets is a privilege of being as they are in business. Michael Chu. (2007) provokes to legitimate bond markets and share markets that should welcome microfinance, issue shares and accept them as businesses turn to a profit. However, Chu legitimizes MFIs high-interest rates because they are short in duration and limiting compounding interest. According to Chu (2007) although there is huge debate on MFI sustainability; however, MFIs key success factors are their loan pricing is set by market forces alone and client selection is at the sole discretion of the microfinance institution. As MFIs are run their programs as businesses; therefore, the risk is borne entirely by the microfinance institution. 
'Doing well by doing good: The future of microfinance via regulated financial institution' paper written by Rosengard (2001) who talks on micro-finance works better with poor in developing countries those are unbankable. Because there is an enormous, diverse potential market for microfinance in developing countries. For example, Bank Rakyat Indonesia (BRI) is the best example that works well for poor and brings longevity of impact to poor although it is regulated by the Indonesian government. Rosengard takes both sides of pro-profit MFIs and subsidized MFIs when full cost recovery is not possible as both of them contribute good results than other organizations in the society. According to Rosengard banks and other regulated financial institutions bring competitive advantages in managing financial risk, in raising their own funds, in establishing extensive retail distribution networks, and in offering a wide range of financial services. All these positive experience he finds in Bank Rakyat Indonesia (BRI).

Rosengard (2001) finds that some MFIs have poorly designed loan products, poorly designed savings products and inappropriate organizational structure that need to improve their capacity buildings. However, the questions are regulated micro financial institution has been need to achieve long-term sustainability, access to funds for certain periods of time, improved governance operations to enhanced customer services. BRI is a social economy organization in Indonesia; therefore, subsidy incentives could encourage BRI to massive reach to poor people across Indonesia.

Drake and Rhyne (2002) in their book The commercialization of microfinance talk about their MFIs survey conducted in Latin American countries in 1990. The survey findings state about results of continuous increase regulation in MFIs in Latin American countries like Bolivia, Columbia, and Peru; and their mission drifts from social to economic and commercialization transformation. According to Drake and Rhyne (2002) the transformation of commercialization is dangerous for many reasons such as (1) more commercial banks are using 'microfinance best practices' than ever before, (2) some commercial actors have been able to reach tens of thousands of clients quickly, at minimal cost to donors, and (3) commercial institutions of all shapes, sizes, and orientations have entered the market (Drake \& Rhyne, 2002, p. 46). They draw a conclusion from the experience of fifty-three banks down scalars that have entered the microfinance world since the mid-1990s (Drake \& Rhyne, 2002, p. 46). The study also mentions that almost 78 percent of the micro-banks responded that they are profitable. However, only three Latin American MFIs have over five thousand loans-an indication that they have experienced slow growth rates (Drake \& Rhyne, 2002, p. 55). According to them, small banks generally integrate microfinance better than large banks. However, they find the greater constraining appears to be obtaining operating resources needed to grow the program- for setting up branches, hiring and training staff, and developing interface systems.

Here authors responding to these challenges are (1) the operational champion- a need for a strong commitment to microcredit from high levels of the bank. Without an internal champion, success is tough. (2) Separate the micro lending program from the organizational culture of the larger bank. (3) As donors consider support for commercial down scales, there are two principal questions to be asked.

Mark H. Moore (2000) in his article Organizational strategy in for-profit, non-profit and governmental organizations mentions that an organization can be said to have a strategy when the leaders and the organization as a whole have committed themselves to a particular vision of how the organization will operate to create value and sustain itself in the immediate future (Moore, 2000, p. 183). He argues that the differences arise from two key differences between the organizations that operate across the sectors. The first difference is the defining source of revenues to the enterprise and second organizations have the social mission (Moore, 2000, p. 185).

Private business has no commitment to the well being of society. Contrarily one important characteristic of non-profit and public organizations is they do not necessarily expect to earn revenues simply by achieving their mission or by making progress towards it (Moore, 2000, p. 193). The article mentions three strategic models for government managers developed by the Kennedy School: The first point-labeled value-directs managerial attention to the value proposition that guides the organization. Second point-labeled legitimacy and 
Views and reviews of microcredit thoughts and MFIs services in the world

support-directs managerial attention to the question of where the support for pursuing the value will come from. Last third point-labeled operational capacity-focuses attention on the question whether sufficient know-how and capability exist to achieve the desired results (Moore, 2000, p. 198). Nevertheless, all these organizations can benefit from developing the above stated three strategies.

The economics of microfinance written by Beatriz Armendariz de Aghion and Jonathan Morduch (2005) aims are to describe the innovations that have created the microfinance movement. Their aim is to address and clarify the puzzles, debates, and assumptions that guide conversations and is to tackle the myths that have made their way into conversations on microfinance. According to Aghion and Morduch (2005), the first myth is microfinance is essentially about providing loans to poor. The second is the secret to the high repayment rates on loans is tied closely to the use of the group lending contracts made famous by Bangladesh' Grameen Bank and Bolivia's BancoSol. The third myth is that microfinance has a clear record of social impacts and has been shown to be a major tool for poverty reduction and gender empowerment (Aghion \& Morduch, 2005, p. 4). However, here the problem is profitability has been elusive for most micro-financing institutions. This book also narrates a Bangladeshi microfinance organization named Association for Social Advancement (ASA). In 2003, ASA provided banking services to nearly 2.3 million customers in Bangladesh. Its loan recovery rates is 99.9 percent and its reported revenues has fully covered costs in every year since 1993 (Aghion \& Morduch, 2005, p. 1).

In the article Microfinance promise, Jonathan Morduch (1999) relates NGOs with MFIs. Here he strongly believes MFIs do good things in societies in both developed and developing societies. He says," Alleviating poverty through banking is an old idea with a checkered past. Although poverty alleviation through the provision of subsidized credit was a centerpiece of many countries' development strategies from the early 1950s-1980s; however, these experiences were nearly all disasters in everywhere in the world" (Morduch, 1999, p. 1570). Conversely microfinance movement after the 1980s has lifted the profile of NGOs. Most programs today continue to be subsidized directly through grants and indirectly through soft terms on loans from donors. However, recently many donors withdraw their support to MFIs and provide support to corporate businesses and accelerate trade liberalization policy. Although these MFIs rated them good in terms of high repayment rates; however, that has seldom translated them into profits and are not serving the poorest clients. Moreover, donors are pushing for the end to MFIs subsidization.

Furthermore, Morduch's article mentions that Grameen group lending is a major innovation in the micro-finance sectors, but it is not the only mechanism that differentiates microfinance contracts from standard loan contracts. This system has dynamic incentives, regular repayment schedules, and collateral substitutes all help to maintain high repayment rates. This peer lending process helps peer mentoring and peer selection among borrowers. Morduch finds Grameen is surviving financially by avoiding taking subsidies from outside.

GB thinks that donors can be fickle because donor budgets are limited, subsidy programs can be inefficient, and subsidies can end up in the wrong hands. However, many organizations are screaming for loan funding and they are depending on external funding. Therefore, it is difficult to measure return on investments because programs are highly cost sensitive as these loans are very costly. However, it needs to be careful if it wants to keep the focus on poverty elimination through high-cost loans. It is possible to lend profitably to low-income households, but it takes time borrowers to become potential for bigger loans. Therefore, seed funding even grants for operating the program is essential for a certain period of time. Donors can phase out their support and withdraw the support depending on MFIs schedule of plan for sustainability. The world is in IT era, but many MFIs are not IT-intensive because of lack of IT skills among MFIs executives and employees. Donors could support to MFIs' IT institutional capacity building of different MFIs those are suffering from lack of IT skills.

Schlefer and Stuart (2005) in their article Corporate Values and Transformation: The Microlender Compartamos mentions that Comparmatos is the largest microfinance institution in Mexico registered under Mexican law as a non-profit anti-poverty organization. It collected funds to feed malnourished children, provided maternal care for indigenous women and its Generadoras de Ingross program provided small loans to 
women-owned microenterprises. Generadoras program follows Grameen Bank per lending 'village banking' method, lending to groups of 20 to 40 women in a cooperative. Generadoras reached financial break-even in 1995 with 17,500 clients and a portfolio of nearly $\$ 600,000$ US dollars (Schlefer \& Stuart, 2005, p. 2). By the end of 2000, Compartamos had moved into urban as well as rural areas across Mexico. Compartamos faced two looming problems. It had become an awkward legal hybrid, a non-governmental organization providing food and medical programs that required subsidies. On the other hand, microfinance services that made a profit (Schlefer \& Stuart, 2005, p. 4). So Generadoras micro-financing covering costs and Generadoras subsidized food and medical support is opposite to covering the cost. Dual policy in the same organization is contradictory to each other. However, for example, if we look at the Grameen Bank microcredit program and Grameen Health Care Services are two separate organizations and they have two separate policies.

Compartamos the lender finally split from Compartamos the anti-poverty NGO in 2000 to become a regulated financial institution (Schlefer, 2004, p. 12). Compartamos hired a young Peruvian woman to run Mexico City loan operations. However, while she increased the number of loans, she turned a blind eye to the breaking of many rules and eventually corruption took root.

Michael S. Barr (2004) in his article Microfinance and financial development attempts to bridge that gap in policy formulation and smooth execution of MFIs. Moreover, this article argues that microfinance can play an important role in financial development by focusing on microfinance policy development and links between financial development, economic growth, and poverty alleviation. Barr urges rather than focusing exclusively on microfinance as an anti-poverty strategy, microfinance should be seen as an integral component of a developing country's broader financial development strategy. The article mentions, "By demarginalizing microfinance programs serving the poor, international financial institutions, donor nations, and developing countries may be able to move quickly reach the Millennium Development Goals" (Barr, 2004, p. 274). Moreover, Barr suggests for the new economic theory that promotes financial development, can contribute to economic growth, and contribute to poverty alleviation (Barr, 2004, p. 275). However, Barr (2004) cautions inequalities can be perpetuated or worsened through unequal access to a growing financial sector in the communities. Therefore, his emphasis on good governance of financial development, appropriate guidelines and supervision of the financial sector- can contribute to financial crises that harm the poor the most (Barr, 2004, p. 277). However, there can be a danger if microfinance institutions grow and increased competition will result in better borrower choice among lenders, which can mean higher default rates as the bond between borrower and lender weakens (Barr 2004: p. 292).

From 1995, Bangladesh micro-financing services are suffering from competition and overlapping of loans to same persons in same area. Bangladesh Bank gives license to MFIs where other MFI has been operating in the same area. Micro-borrowers receive microcredit from different MFIs those are near to them by hiding their existing loan transactions with other MFIs. As a result, it is found that many clients are receiving more than one loan from their neighboring other MFIs. As they receive more loans than their investment capacity, many clients become defaulters. So now the harmonies of creditworthy of the micro-borrowers are in question in Bangladesh. Grameen Bank has been protesting against this policy, operate more MFIs in one area, since 1980s; however, state overlooks this problem.

Stanley Fischer (1991) aims in his article Does macroeconomic policy matter? Evidence from developing countries finds that to establish-or re-establish that macroeconomic politics matter for economic growth and development. By macroeconomic policies, Stanley Fisher (1991) means that monetary, fiscal and exchange rate policies that help determine the rate of inflation, the budget deficit and the balance of payments (Fischer, 1991, p. 7). Stanley (1991) calls it 'lost decade' (1980s) for developing countries in Africa and Latin America because of their negative socioeconomic growth. From 1980 to 1989 their GDP rose only less than 1 percent per year, and per capita, GNP fell more than 25 percent (Fisher, 1991, p. 22). These countries are affected by their macroeconomic policy focus on structural adjustment, domestic, external macroeconomic policy equilibrium and globalization process. Governments cutting their expenditures on education, health, housing, wages of the 
employees, reform the tax and other sectors that affects public life. As the decade progressed and the consequences of macroeconomic disequilibrium became clearer, hence broad macroeconomic stability is necessary for sustained growth. Therefore, Stanley Fischer believes in the new growth theory that focuses on the role of technology, international trade, human capital, the economics of scale, and the possible need for a coordinated big investment push break out of a low-income equilibrium (Fisher, 1991, p. 6). The black market results in more inflation in those countries (Fisher, 1991, p. 38). To overcome these challenges, he suggests that short-term macroeconomic policies have better tend to grow faster, but there need political stability, a potential link between inflation and economic growth. Otherwise, growth economy becomes volatile because inflation and budget deficit are affected by the growth rate (Fischer, 1991, p. 8). The good governance of the public policies and executions of programs, transparency, and accountability also responsible for developing countries lost decades.

According to Aghion and Murduch (2005), the basic economic principle of micro-credit is of diminishing marginal returns to capital, which says that enterprises with relatively little capital should be able to earn higher returns on their investments than enterprises with a great deal of capital. Poorer enterprises should thus be able to pay banks higher interest rates than richer enterprises. Aghion and Murduch (2005) anticipate that the microcredit movement continues to be driven by hundreds of millions of dollars of subsidies with a hope that microfinance programs will use the subsidies in their early start-up phases only. After 3-4 years their operating costs down and programs will eventually be able to operate without subsidy (Aghion \& Morduch, 2005, p. 17). In addition, MFIs also need support for to develop their institutional capacity building and to develop employees' skills.

The key productivity variables in MFIs can be found in the projection of the microcredit branch-level operations through MFIs loan portfolios, income, and staffing spreadsheets. However, according to Peck Christen (2003) in his article Banking services for the poor: Managing for financial success that financial viability is largely determined by the MFI's service delivery technology and interest rate policy (Christen, 2003, p. 240). Although it is important to use local currency; however, he raises questions what currency should be used for MFIs incremental projection. The usual answer is MFIs normally use local currency for their loan operation and reporting. Moreover, Christen (2003) raises the issue of the most useful ratio number of clients per field officer. This ratio helps the program to avoid increasing the number of clients beyond the ability of the staff to serve them. The notion of optimum ratio number of clients per loan officer and reduce additional bookkeeping jobs are crucial for MFIs. In Grameen Bank, loan officers are overloaded with the ratio of loan; that is why the quality of center management of Grameen Bank by its loan officers becomes weak since 1998.

Gabriel Szulanski (1996) writes the article Exploring internal stickiness: Impediments to the transfer of best practice within the firm raises the issue of the notion of internal stickiness connotes the difficulty of transferring knowledge within the organization (Szulanski, 1996, p. 29). The sticky information is difficult to transfer and have the incremental cost of transferring the information. Szulanski says that the cost might fail to discriminate between problems that are equally costly, but qualitatively very different (Szulanski, 1996, p. 29). According to Szulanski there are four sets of factors influence the difficulty of knowledge transfer. Characteristics of the knowledge transferred are (1) Causal ambiguity, (2) lack of motivation, (3) unproven and (4) not perceived as reliable. Yes, the characteristics of the recipient of knowledge and characteristics of the content are very important in the transfer of knowledge. For example, lack of absorptive capacity and lack of retentive capacity affect the transfer of knowledge effectively for knowledge retained and persistence. All are most important impediments to knowledge transfer within the firm.

Stuart (2002) writes the paper Women's thrift cooperatives in Andra Pradesh. Stuart studied 15 associations of women's cooperatives (AWTCs) and nine associations of men's cooperatives (AMTCs) in the Warangal and Karimnagar districts, in Andhra Pradesh in India in 1999. All these associations are supported by the Cooperative Development Foundation (CDF) India (Stuart, 2002, p. 1). In 1993, CDF changed its course a little: instead of lobbying for a change in the existing cooperative law, it lobbied for a new, parallel law under which cooperatives 
could opt to be regulated. It was succeeded opt to change cooperative laws to providing loans to the women with the existing financial institution and allowing them to build their own institutions according to their own ideas and the cooperatives. From then the cooperatives were self-managing-and self-financing-organizations. However, the cooperatives' presidents elected the directors and president of the association (Stuart, 2002, p. 5). It is like Big Carrots in Toronto where its board of directors decided on loan applications from members is complicated. This is a top-down approach to loan approval that might inappropriate to the loan receiving clients.

Although CDF cooperatives allowed savings; however, the loan amount a member is allowed to borrow is limited to three times their thrift savings balance. Moreover, elites' signatures as guarantors on the loan applications require, which does not work to prevent defaults. Recently CDF promoted the idea of Joint Liability Groups (JLGs) in loan disbursement process like Grameen Bank, but CDF makes one strict rule the prohibition against cooperative leaders running for political office to protect the cooperatives from riders influence and corrupt cooperatives. However, this prohibition caused tension within the cooperatives (Stuart 2002: p. 19). Contrarily, Grameen Bank encourages borrowers to participate at all levels local, district, regional and parliamentary elections. In 1993, 23, 500 borrowers of Grameen Bank ride local council election. Among them, 657 were elected as chairman of the local councils, 12,450 were elected as members of the local councils. These numbers are increasing in the consecutive elections. There is no negative affect like influence by the elected chairmen/members in the centers of GB noticed.

Patten, Rosengard, and Johnston (2001) writes the article Microfinance success amidst macroeconomic failure: The experience of Bank Rakyat Indonesia during the East Asia crisis. Bank Rakayet Indonesia (BRI) is one of three state-owned commercial foreign exchange banks in Indonesia. BRI is owned entirely by the government but operates under all of the prudential norms and regulations that every commercial bank must adhere to in Indonesia. BRI's primary mission is the provision of rural and urban community banking services by mobilizing family savings and delivering credit products to medium, small and micro-enterprises. During 1997, the East Asian crisis hits, BRI re-organized into four strategic business units (SBUs) to reconstruct its banking activities in Indonesia: SBU Microbanking is in charge of BRI's 3,694 units, SBU Retail Banking is in charge of BRI's branches, which provide full banking services to people; SBU makes large corporate loans, and SBU Treasury and Investment purchase of Bank Indonesia certificates.

These new BRI' SBUs contributed to ending up the crisis in Indonesia in 2000. For example, the minimum interest rates on most small, medium and large loans in Indonesia fallen to 19\% from 36\% in 2000 (Patten, Rosengard, \& Johnston, 2001, p. 1060). The BRI units have a single credit instrument KUPEDES (General Rural Credit). All KUPEDES loans require repayment in installments. During the worst of the monetary crisis, there was a very rapid increase in savings, both in the BRI units and in the rest of BRI (Patten, Rosengard, \& Johnston, 2001, p.1064). These amazing performances and contributions make a positive impact on Indonesian national economy by this micro-financing community banking in crisis periods of Indonesia.

In the article Patten, Rosengard, and Johnston (2001) identify four factors that explain the excellent repayment performance of BRI's microenterprise borrowers, as compared to small, medium and large enterprise borrowers: (1) The microenterprise loans are all instalment loans adjusted to the borrower's cash flow, (2) The microenterprises are more likely to be engaged in the purchase and sale of domestically-produced essentials, (3) The rural sector less affected by the monetary crisis than the urban areas, and (4) the microenterprise borrowers value their access to credit and savings services very high. BRI able to develop a strategy that promotes borrowers willingness to repay like develop a long-term banking relationship with borrowers and loan delivery systems that are adapted to local market conditions (Patten, Rosengard, \& Johnston, 2001, p. 1067).

The article entitled Sustainable development: Mapping different approaches written by Bill Hoopwood, Mary Mellor and Goeff O'Brien (2005) talks about environmental, social and economic justice issues and sustainability approaches that can promote business sustainability. They espouse that in the last couple of years, the environment has been viewed as being external to humanity. The authors of the paper link socio-economic 
environmental sustainable development with environmental and socio-economic issues and claim that mainstream economic policy is dominating international property human beings and expanded global trade. However, past economic growth models fail to eradicate poverty globally and locally. This economic growth creates a downward spiral of poverty and environmental degradation. Therefore, social justice is a crucial component of sustainable development. Micro-financing institutions should maintain these points in their program operations. To achieve sustainability, authors analyze the status quo approach; the reform approach and the transformative approach; and include eco-feminists' and eco-sociologists' attitudes towards sustainable development.

'Engaging fringe stakeholders for competitive imagination' paper written by Hart and Sharma (2004) mention that government power has eroded by globalization and growth of traditional corporations in different countries. NGOs and civil society stepped into the break of their expansion. The internet-connected coalition of NGOs, individual and smart mob make it impossible government and corporations to do monopoly decision for the public. To avoid the extreme danger of mob, it needs to proactively seek voices from the fringe that previously ignored. Therefore, the firm needs to consider strategic management process. Authors use the term 'Radical transactiveness' (RT), which focuses on gaining access to stakeholders to manage disruptive change and create competitive imagination among them. Hart and Sharma's the RT strategy are put the last first for include those are powerless, non-legitimate and isolated. Unfortunately, most companies still tend to focus management attention only on known, salient, or powerful actors to protect their advantages in existing businesses.

\subsection{Politics of microcredit}

Vogel and Burkett (1986) write down the article 'Mobilizing small scale savings, approaches, costs and benefits' published by The World Bank, Washington D.C. Recently maximum MFIs are increasingly mobilizing savings from credit unions borrowers in India and BACOOP borrowers in Peru. However, Vogel and Burkett identify that there has been little systematic analysis of the benefits and costs of such programs due to the prior focus of governments, international donors and the financial development literature on credit rather than savings in Indian MFIs. However, the article finds Indian non-wealthy households benefit from improved deposit opportunities provided by safe, liquid, interest-bearing deposits that allow these households to earn a positive income on their savings balances and avoid the erosion of these balances by inflation (Vogel \& Burkett, 1986, p. $\mathrm{V})$.

The author also finds postal savings have been an important vehicle for mobilizing financial savings in India, Nigeria, and Peru. These case studies also indicate the crucial role of financial innovation and reciprocity in determining the viability of credit branch office expansion as a tool for improving deposit opportunities in these developing countries. Give interest to savings balance encourages people to savings deposit in the bank; however, in the developed country like Canada, USA, and UK do not provide interest to clients' current accounts. Therefore people's savings tendency is less in North American countries.

'The disciplinary power of micro-credit: Examples from Kenya and Cameron' is a research paper written by Lairap-Fonderson (2002). The author's research has made her believe that micro-credit to women in general, and to sub-Saharan African women in particular, acts more like a disciplinary power, turning them into 'efficient economic actors' that must perform in the market economy, rather than as a tool for their empowerment. This paper study Kenyan Women Finance Trust (KWFT) and Cameroon micro-credit organization NJANGI Cameroon; and makes a case study and critical analysis, and compares them with Grameen Bank Bangladesh microcredit program. Lairap-Fonderson finds Rotatory Savings and Credit Association (ROSCA) program is very popular in sub-Saharan countries. In Kenya, embraced/adopted micro-credit (the 1980s) earlier than Cameroon (1990s)-so comparing the situation in these two countries is interesting. Although sub-Saharan African countries' socio-economic, geography and geopolitics' features are different than Bangladesh and Canada; however, this article gives me an example and idea on critical analysis of micro-credit impact to marginalized women in Africa. ROSCA is an informal initiative of savings and investments among ROSCA 
members; however, many ROSCA studies find there are lots of conflicts among ROSCA members regarding ROSCA saving defalcation. Therefore, ROSCA each member should regularly watch what is going on the ROSCA savings money.

Bjorn Nordtveit (2015) writes the article 'Producing literacy and civil society: The case of Senegal'. The literature findings of Bjorn Nordtveit (2015) in a Senegalese study talks about the importance of integrated micro-credit in the lives of Senegalese. Its findings assert that micro-credit increased a mother's support for her children's education, empowered women, made communication more effective through client networking and improved the livelihoods of participants. These MFIs are NGOs that are an alternative route to the well-being of marginalized micro-borrowers. Nordtveit (2015) uses both qualitative methods, (interviews with local people, observation, and personal experiences); quantitative statistical analysis in producing "Literacy and Civil Society" paper in his Senegalese case study. The integrated microcredit approach is welcomed by all; however, Bjorn Nordtveit did not explain how Senegalese integrated microcredit is working, what the source of funding is and what the cost of return on investment is. However, the Senegalese integrated microcredit program provides readers a practical sense of integrated microcredit program which is different from single-minded micro-financing.

Adopting Maria Manzon's theoretical framework, which draws on Foucault and proposes that comparative education as an academic field is socially constructed, but I think that the field is neither stable nor well defined. To demonstrate this, I conduct a content analysis of the Comparative Education Review, using Klaus Krippendorff's methodological framework to study comparative and international education (CIE) researchers' understanding of the national - and of their related knowledge production in the field. Many comparativists express interests in multiple countries, and their knowledge production takes the form of individual country studies.

The countries are habitually studied using a "problem approach" focusing on one specific aspect of the country under investigation and using an associated social science methodology deemed appropriate. Few comparativists are making explicit use of or reference to any methodology that is unique to comparative education. Efforts to catalog and systematize CIE research have demonstrated that the field is becoming so inclusive that it hardly is distinguishable from educational studies as a whole. Hence, I suggest that instead of speaking about unifying features of the field, it may be more relevant to speak about frequent elements, such as a focus on the national, and a knowledge production characterized by the academic-practitioner who desires to improve the education systems studied. A third frequent element may be the focus on educational development, thus justifying the label of "comparative, international, and development education." One challenge of the field is its dependence on Western social science discourses, which may be marginalizing other voices.

Karim, Lamiya (2001) article written by 'Politics of the poor? NGOs and grass-roots political mobilization in Bangladesh talks about how micro-borrowers exploited by MFIs in Bangladesh'. She comments that poor people in Bangladesh are empowered themselves even do not develop their citizenry skills through Bangladeshi MFIs. Traditional money lenders do not lend to the very poor, who are the target groups of the NGOs. The commercial bank does not lend to the poor, who lack physical collateral. Thus these micro-lending NGOs have become the only source of capital for the financially strapped poor people. Lamiya (2001) comments that this financial dependency has enabled the NGOs to bring the rural poor into new structures of subordination, altering existing codes of conduct for rural women and subjecting them to their own political work and priorities. However, this relationship with the poor allows the NGOs to inaugurate itself as the friend of the poor. Through rallies and other gatherings, many NGOs speak for the poor- but that this voice is the voice of the patron-in a patron-client relationship (Lamiya, 2001, p. 93). However, these NGOs in Bangladesh are highly dependent on donor funds for the financial sustainability of their projects. If donor stops funding, their advocacy programs finish. Many donor funds are channeled through the large NGOs. A study on NGO in 1992 revealed that only 30 large NGOs in Bangladesh get eighty percent of the total foreign funds given to NGOs, but the sixty percent was controlled by eight largest NGOs in Bangladesh (Lamiya, 2001, p. 95). Maximum donors' agencies are 
surrounded by these eight largest NGOs in Bangladesh; however, all of them are involved in credit delivery services in Bangladesh. In the paper, Lamia Karim raised many questions on micro-financing and its impacts on poor people; however, she does not give any way forward how MFIs should work where poor can get both economic and citizenry benefits.

Badruddin Umar (2001) in his book 'Yunus's poverty trade' states that NGOs preach a kind of economism instead of a political progressive consciousness in Bangladesh. Their goal is the extension of credit instead of sociopolitical development. In this way, political outlook is hijacked in Bangladesh. Microcredit shift borrowers' conception about their location in the society. There is no citizenry skill development by Grameen Bank even other big NGOs in Bangladesh. For example, borrowers are now individual entrepreneurs in the community and become individualism into their networks of social relations. They are now engaged in income generating projects; do not think themselves as laborers, but owners of petty capital. Although these NGOs are saying they are working for increasing income of the poor; however, very few people are able to come out of the vicious circle of poverty. Rather, many micro-borrowers stay in deep poverty, suffering from malnutrition, health care facilities social injustice and lack of education.

\subsection{Empowering disadvantaged women and modernism}

Mahamud (2004) written the research article Micro-credit and women's empowerment in Bangladesh in Attacking poverty with micro-credi. (Eds.), Salehuddin Ahamed and M. A. Hakim. Dhaka: Dhaka University Press. Simeen Mahamood (2004) in her above article examines whether MFIs in Bangladesh contribute to women's well-being in broader perspectives and tries to find relationships between microcredit program participation and the process of empowerment. However, the norms and practices in the country place women in subordinate positions to men, which means they have a lack of choice and little power in the decision making process in their private sphere, family sphere and public sphere; however, Rouf (2011) survey on Grameen Bank women borrowers finds that $87 \%$ women directly and indirectly involved in their family decision making process. More than $90 \%$ women micro-borrowers are freely moving, visiting public spaces like schools, bazaar, banks, hospitals, courts and other public places. If I compare the Mahamud' findings with Rouf's findings, it indicates that women micro-borrowers are in the advanced stages of empowerment in Bangladesh and it is still progressing.

Microcredit: The Rhetoric of Empowerment, the Reality of 'Development as Usual' is a paper written by Isserles (2003). This claims the realities of microcredit and its impact on Grameeen women in 1998-1999, but Robin Isserles uses 1990s secondary data in his study. Although his narratives documented Grameen Bank has seen many success stories of women overcoming poverty through its loans; however, Isserles cautions that many women are still dominated by their husbands. Female borrowers are not free from their husband's control over the loans. Here he recommends that after receiving loans women must be provided with additional supports so that they can empower themselves and be free from existing male-dominated power relations in their homes. This critical analysis/themes can be used my research paper. Empowerment is a process and it is related to many factors, indicators, and context. Using one indicator for measuring women empowerment in Bangladesh is not enough.

Goetz and Gupta (1996) writes her anthropological research paper 'Who Talks the Credit? Gender, Power, and Control over Loan Use in Rural Credit Programs in Bangladesh'. Their paper investigates the degree to which women actually control the loans, which they have access to through numerous credit institutions in Bangladesh. Despite an excellent repayment rate, their research findings indicate that the majority of loans to females are controlled by male relatives. This would mean that the objectives of credit being an empowering tool to women would not be met in these MFIs programs. Goetz raised many issues in the paper like credit is supposed to help women but women borrowers are suffering from mental torture for every week repaying her loan. 
The main question of this paper is how much of the credit do women actually control? She thinks women micro-borrowers still receive an extremely small proportion of the cumulative amount of loans. Many defaulter borrowers' loans are adjusted with the new loan disbursement by their loan officers. This is a bad practice in MFIs. Other questions are about the impact of credit on women in terms of its effects on intrahousehold decision-making, resource allocation, and empowerment. These are valid points but it's really not something that can be studied be quantified. Are these financial institutions just using poor women as a market for their goods? They do charge very high interest rates. It has seen happen before with colonialism! Inclusion in the economy does not equal to power. The study finds- a significant amount of women who borrow from MF institutions do not have control over the money they borrow.

The study finds many ambiguities surrounding control over loan use-an apparent loss of control rather led to violence. The paper asserts women disguise a negotiated transfer- the rights and privileges gained in return; this may indicate a power achievement for the woman borrower; but in reality it is a hardcore fact for the women. Although the study finds many women have significant control over decisions relating to family health and dowry but these are not over productive activities. According to feminists, this is just pushing women deeper into the cycle of being exclusively responsible for taking care of the family. The paper is very thorough. According to her women are just good middle-"men" between financial institutions and men. It is sad in the patriarchal society; women are used in many ways with no recognition on so many levels. Nonetheless, it is true Grameen bank doesn't support any skill development on gender awareness among its borrowers.

These are very important because increase women income does not mean their status in society and in the households increase rather, very often men get mad that women are doing something that's not their business. Women don't have access to the actual market. It is done by male members of the family. Women micro-borrowers actually used by their male partners who are using the loans. The paper contains both quantitative and qualitative study. The paper itself is not able to provide solutions for the issues it raised. Skills development and gender awareness programs are very effective to poverty eradication and empowerment; unfortunately, MFIs skips from these jobs.

Hickey and Mohan (2004) write the article Relocating participation within a radical politics of development. Samuel Hickey and Giles Mohan in their article discuss the issue that beneficiaries' participation being necessary for their sustainable development and empowerment. However, contemporary development NGOs focuses on imminent (forthcoming) change rather than immanent (existing within). They are not involved in the wider structures of injustice and oppression, and insufficiently look at how power operates and they are constituted, rather they are projects based organizations. They fail to deal with the issue of politics and power.

NGOs have a tendency to avoid relationships with political elements and tend to bypass beneficiaries' rights-based development. For example, Grameen Bank (GB) shifted to a self-sustaining bank that gives it greater access to funds and offers higher loans to its members. However, this profit-making focus diverts employees to only on credit disbursement, collect repayment installments and attentive to high repayment rates rather than focusing on resource development, social and citizenship development issues. This article is a political economy analysis of microcredit that refers to Grameen Bank single-minded micro-financing in Bangladesh. Grameen Bank microcredit is an economic program deals with providing loans to poor people in Bangladesh. Grameen Bank does not do or mandate for all jobs that could address health care, citizenship education, vocational skills training and infrastructure development etc. jobs in Bangladesh. However, Grameen Bank Sixteen Decisions are a campaign for the borrowers' socio-economic development in Bangladesh. This campaign creates awareness among the borrowers of Grameen Bank in Bangladesh. Moreover, Grameen sister organizations are working on renewable energy, healthcare, providing vocational training and child education services in Bangladesh since 1998. However, here the question is how participation can be approached in a way that makes it transformative and empowering for excluded mivro-borrowing groups? This paper suggests for relocating participation within a radical politics of development outlines a critical modernist approach to capturing the complex and political character of popular agency within the development process. It also 
examines the democratic values underpinning this transformative politics of difference and develops a radical notion of citizenship as a form of analysis and guide to strategic action. Moreover, here authors tackle responses to criticisms raised against participation, notably those of 'post' and 'alternative' development.

Post-development approach sees participation as linked to the dominating and homogenizing project of development. This view advocates abandoning modernity in favor of a romanticised vision of pristine alternatives. These seem to bear little relation to the demands of the actual social movements on which these theorists base their work. Alternative development views participation as domesticated away from its radical roots and seeks a return to radical participation. However, this approach is not convincing in terms of theory and praxis, but it underplays the role of the state and glorifies the local. Here both these concepts are a caricature rather than engage with 'development' as a complex process, and fail to analyze how political economy shapes agency within development because critical modernism is a socialist-inspired framework that advocates rethinking development rather than simply rejecting it. It retains faith in central aspects of modernism such as democracy, emancipation, development, and progress.

Critical modernism entails a belief that modernism is not a singular entity, but that its ideas and practices are appropriated in locally situated practices. This means that modernity is fragmented into much different modernity. However, this does not mean that all identities and rationalities are equally valid: There is an ethics of development, whose starting point is the existence of widespread poverty and the struggle for social justice. However, the question is how can a development tied to a politics of social justice resolve the tension between this universal value and multiple nationalities? This politics of difference requires not the dissolution of difference, but institutions that promote the reproduction of, and respect for, difference.

Another important conceptual response to the backlash against participation is a focus on 'citizenship'. This captures the wider sense in which popular agency exists, and broadens the debate to cover aspects of governance. Because citizenship is the set of practices (juridical, (judicial, administrative law), political, economic or cultural) which define a person as a member of society and shape the flow of resources to persons and social groups? This means that participatory interventions will have the aim of enhancing the competence of participants to project their agency into broader arenas, thus altering the immanent processes of inclusion and exclusion. However, citizens' participation is a 'civic republican' involvement rather than liberal theories of citizenship best capture this vision. These are based on the collective and participatory engagement of citizens in community affairs, rather than solely narrower forms of engagement, such as voting. It should also consider less 'public' participatory arenas relied upon by subordinate groups of the community. Therefore, the realization of the critical modernist project will require a form of radical democracy that transcends the local and forges alliances with a range of regional, national and global movements. Moreover, citizenship covers both participatory development and participatory governance and also links to rights-based approaches since it establishes participation as a political right. Citizenship is an inherently political perspective on participation, perhaps the chief requirement of contemporary approaches to participation. Unfortunately, maximum MFIs are not directly involved in right-based citizenship development approach in the world, which is crucial for disadvantaged people social and political empowerment.

Aminur Rahman (1999) writes his anthropological research paper Micro-credit initiatives for equitable and sustainable development: Who pays? The main theme of this paper is despite the success of the Grameen Bank in delivering loans to poor women and bringing socio-economic changes to many of these women's households, Aminur Rahaman (1999) findings indicates that there are still many borrowers who become vulnerable and trapped by the system; they are unable to succeed to lift-up their socio-economic development (Rahman, 1999, p. 68). Aminur Rahman mentions that GB has two faces: public and hidden transcripts'. In the paper, he examines 'public and hidden transcripts' in GB impact analysis. The public transcripts of GB offer only a partial view of the process and are influenced by the desire to see success in equitable and sustainable development; hence it obscures a fuller understanding of the process (Rahman, 1999, p. 68). Hidden transcripts: The bank extends loans to women, but community men predominantly use these loans and supply installments to women for their 
Rouf, K. A.

weekly payment in the loan centers (p. 69).

Rahman comments grameen bank uses group peers support lending system as social collateral instead of material collateral. However, I think Aminur miss GB micro-borrowers social capital development and leadership development through Grameen Bank group-based lending system. Many studies acknowledge women borrowers of Grameen Bank social capital development. Social capital development and leadership development is a continuous process. Rouf (2011) finds $87 \%$ borrowers of Grameen Bank social capital and leadership development has achieved but still it is progressing.

\subsection{Design business that can serve the bottom people}

BlueOrchard Finance: Connecting microfinance to capital markets written by Jean- Philippe de Schrevel (2004) mentions that BlueOrchard Finance is a Swiss Company specialized in the management of microfinance investment funds. The company's mission is to improve the connection of microfinance organizations with capital markets with a view to enabling them to increase their economic and social impacts at the grassroots level in their respective markets. Jean- Philippe de Schreve is the founder of the BlueOrchard Microfinance Capital Foundation (BMCF) and the BlueOrchard Finance runs through/from BlueOrchard Microfinance Capital Foundation (BMCF). It is a non-profit company in Switzerland. It provides wholesale loan capitals to the world lead MFIs with the following characteristics: a minimum two-year microfinance track record, a minimum asset size of USD 1,000,000 and acceptance of external audit. Its schemes are in India, the Philippines, and Columbia. It does not need formal guarantees from the MFI or from the respective state. However, BlueOrchard faces some issues like many MFIs (funds received from BMCF) prefer to work with donations over commercial finances; legislation often limits or forbids loans to MFIs, and convincing the authorities. However, BMCF works in this constraints situation and is able to increase/grow its funding to many MFIs in India and in Latin America, and able to attract MFIs to meet their equity investment needs (Schrevel, 2004, p. 10).

Coyle a famous adult educator in Canada, writes a paper Small is beautiful, big is necessary, Canada's commercial and cooperative answers to the global challenge of microfinance access. This paper is a keynote speech at the World Micro-Credit Summit in Halifax in 2006. This paper gives a short history of Canada's cooperative and commercial microfinance innovations and desires for paths and space for to reach large numbers of poor people with appropriate financial services. The Canadian International Development Agencies (CIDA) and other international, national, and local agencies have foreign and domestic experiences in providing micro-finance services in various ways outside Canada and within Canada. However, although Canada domestic micro-finance organizations are suffering from loan capitals for loan investments and organizational capacity building, they get less support from the public sectors and from the commercial banks result in limited scale MFIs contribution for promoting micro-enterprise development in Canada. Hence, Canadian public policy must reflect and address the women entrepreneurship development in Canada. Although Canadian government has open the door of the small business capital for women entrepreneurs; however, newly arrived immigrant women entrepreneurs in Canada need to comply the procedures to get the business. They think the procedures are high stakes for them to get their business loans.

Henry (2006) presented the paper Good practice in business development services: How do we enhance entrepreneurial skills in MFI clients? at the Microcredit Summit 2006 in Halifax. This article talks about Calmeadow Foundation and Alterna Savings micro-finance services in Toronto that have been working to help micro-entrepreneurs by providing loans since 1993. The article narrates that a combination of financial credit, small business management skills training, micro-business mentoring support and operational support is crucial to help micro-entrepreneurs. The integrated financial services and non-financial services can build and enhance increasing their income, productivity, and employment ultimately facilitates the personal growth of the entrepreneurs. However, borrowers need to pay $18 \%$ interest rate that is high for the clients. However, this community micro loans program is not yet self-sufficient. 
Muhammed Yunus (2002) writes a booklet entitled Grameen Bank-11: Designed to open new possibilities where he narrates the new products and new modalities of GB phase-2 in Bangladesh. In 2000, GB reforms its some products and introduced new loan disbursement system called "Grameen Generalized System Grameen Bank Phase -2" where it designed a new operational manual based on its past experiences. Before 2000, all Grameen operations are termed Grameen classical system (phase -1) and after 2000, Grameen operation phase-2. Grameen Bank Phase- two is more flexible and borrowers-friendly system to borrowers to transactions with the bank. The new system main features are prime loan product called the basic loan, flexible loan, housing loan, and the higher education loan and grameen pension scheme (GPS); clients can repay loans according to their income. Weekly savings varies with loan size full repayment at any time allowed. Clients can receive refresh (new loan) loans after every six months on top of the existing loan. Grameen Bank phase introduced Grameen Pension Schemes (GPS). Here clients can deposit their pensions (GPS) premiums monthly basis. The monthly premium is Tk.500. This new GPS system makes revolutionary savings behaviors among Grameen Bank clients. Grameen Bank employees can open GPS account in their own name and deposit their monthly premium in Grameen Bank. GPS creates huge liquidity for Grameen Bank. Here GB many products are more similar to commercial banks' products. However, there are some welfare products to borrowers like struggling members can receive loans without interest that help to hardcore poor to mushroom them/survive them in an adverse situation. I am not experienced with these new products as I am out of Bangladesh since 1998. However, there is no impact study conducted on Grameen Bank phase-2. It would be interesting to do a research on GB phase-2 to know its new products contribution to borrowers' life; as well as performances of the new products of GB phase-2 in borrowers' life.

The fortune at the bottom of the pyramid written by Prahalad and Hart (2002) assert that there are four billion poor people in developing countries who are at the base of the market pyramid. The perception of the bottom of the pyramid is not only that of a viable market but that it also includes informal $60 \%$ of the total economy. According to Prahalad and Hart (2002) doing business with four billion people, requires radical innovation in technology and business models. The poorest people are large in number in the world; therefore, this article raises a new managerial challenge for the wealthiest companies in attempting to settle the poor and helping them to improve their lives and produce products that are culturally sensitive, environmentally sustainable and profitable.

Here authors suggest for a new business model: The Tier- 4 multinational corporation (MNC) business where its market has some core assumptions that are an influence in less developed countries (LDC): (1) the poor are the target consumers because they are not in a profitable market, (2) the poor cannot afford products that are sold in DC, and (3) the bottom of the pyramid is not a long-term viable business. The motive of the private sector is to leave Tier- 4 (the poor) to the government and non-profit sectors because corporate managers are not excited doing business with the poor and MNCs do not have business challenges that are humanitarian. Therefore, it is hard to find corporate managers who agree to work with the bottom of the pyramid. However, Grameen Bank is an exception in this regard.

Prahalad and Hamel (1990) write the paper The core competence of the corporation. According to Prahalad and Hamel (1990), an MNC must make the following changes in order to succeed in marketing to the poor, and to do business following the Tier- 4: (1) Build a local base support with stakeholders, (2) Conduct research and development (R\&D) on the poor, (3) Form new alliances, (4) Increase employment intensity, and reinvent cost structures. However, Prahalad and Hamel do not mention corporate social responsibility, which is essential for restoring the environment and sustainable business development. Therefore, it needs to add corporate social responsibility (CSR) to its list in order to ensure a sustainable business model because only the most solid and sustainable businesses will survive into the coming centuries. Moreover, Prahalad and Hamel do not mention social value capital development in their 'Bottom Pyramid Tier-4 approach'. However, social business enterprises (SBEs) are very important for value creation and socially-driven ventures. They are designed and operated as a business enterprise to pass on all the benefits to the customers rather than translating them into profits for the investors. The most powerful way to prevail in global competition is still invisible to many 
companies. During the 1980s, top executives were judged on their ability to restructure and delayer their corporations. In the 1990s, they are judged on their ability to identify, cultivate, and exploit the core competencies that make growth possible-indeed; therefore, they'll have to rethink the concept of the corporation itself. Now it is time for them redesign their businesses that could include and serve the bottom four million people in the world.

\section{Conclusions}

In the Harvard micro-financing training program, it is found few discussions were on how to improve MFIs' operations, bookkeeping, and monitoring devices which are crucial for MFIs to improve their efficiency and to reduce their costs. Discussions were tailored to MFIs different policies, strategies and approaches that could benefit the microeconomics, enhance reduce poverty and empower the micro-borrowers. The training articles of this training course are analytical to capitalism, neoliberalism, globalization, trade liberalization and women empowerment. Such articles are usually studying in graduate and postgraduate levels. Many attended trainees were unable to catch the dense writing of many articles. However, Michael Chu, the facilitator of the training program, explains these dense articles in simple language in the training sessions.

The attended trainees assert that the community-based grassroots microfinance organizations need instead analyzing their activities, the MFIs need mentoring from the state, donors, policymakers, academicians, researchers, and practitioners. These grass-roots organizations need close contact with the vulnerable borrows to expose them to be the economic actors and the social actors in the community. Nevertheless, the sessions could emphasis on this issue. Again the paper raises the issues: MFIs need huge record keeping jobs like bookkeeping, create the database, maintaining the database, processing data, monitoring data and reporting to chaining command. Because majority loan officers disburse and collect loans in cash, deposit cash in the bank manually that is risky and time-consuming for them. However, commercial bank develops many alternative IT ways to deal their transaction safely. Here MFIs have a huge gap in efficiently managing their loan transactions and proper record keeping and monitoring. Therefore, MFIs need to develop their IT institutional capacity building on these jobs. MFIs could expedite their activities and reduce their costs through developing their IT capacity. My experience working with micro-financing organizations finds maximum MFIs are doing these jobs manually, so their costs are high and unable to find delinquents in proper time because their monitoring IT system is not updated.

Although many MFIs have computerized their jobs, they are insufficient and imperfect for performing these jobs. However, many of them yet have not able to appropriately computerized and digitize their jobs. Employees are not skilled in IT. Therefore, it is very urgent MFI develop IT appropriate program which could systematize their loan transactions, bookkeeping, and monitoring and data processing jobs. None of these articles and books talks how to improve and reduce the current MFIs loan transaction costs, bookkeeping, and monitoring jobs; digitalized these jobs and perform these jobs efficiently. Nevertheless, above stated MFIs different case studies, articles' different themes, critics, and suggestions deliberated in the training sessions give me to rethink further about future MFIs portfolios; analyze their strengths and weakness in order to understand their importance and contribution in the community especially to the bottom pyramid people.

\section{References}

Aghion, B. A., \& Morduch, J. (2005). The economics of microfinance. Cambridge, Mass: MIT Press.

Barr, M. S. (2004). Microfinance and financial development. University of Michigan Law School.

Beck, T., Demirguc-Kunt, A., \& Levine, R. (2005). SMEs, growth and poverty: Cross-country evidence. Journal of Economic Growth, 10(3), 199-229. https://doi.org/10.1007/s10887-005-3533-5

CalmeadowFoundation. (1995). Self-employment in Canada: Best policies best practices, Toronto, Calmeadow Foundation.

Christen, P. (2003). Banking services for the poor: Managing for financial success, Washington: World Bank. 
Views and reviews of microcredit thoughts and MFIs services in the world

Chu, M. (2007). Commercial returns at the base of the pyramid. Innovations: Technology, Governance, Globalization, 2(1-2), 115-146. https://doi.org/10.1162/itgg.2007.2.1-2.115

Counts, A. (2008). Small loans, big dreams. New Jersey: John Wiley \& Sons, Inc.

Coyle, Mary (2006). Small is beautiful, big is necessary, Canada's commercial and cooperative answers to the global challenge of microfinance access, Toronto: Calmeadow Foundation

de Schrevel, J. P. (2004). Blue orchard finance: Connecting microfinance to capital markets. Harvard Kennedy School.

Drake, D., \& Rhyne, E. (Eds.) (2002). The commercialization of microfinance: Balancing business and development, Bloomfield, CT Kumarian Press Inc.

Fischer, B. (1995). The basic problem in financing small businesses. Economic Growth Center, Yale University.

Fischer, S. (1991). Does macroeconomic policy matter? Evidence from developing countries. Washington: World Bank-IDEP.

Goetz, A. M., \& Gupta, R. (1996). Who talks the credit? Gender, power, and control over loan use in rural credit programs in Bangladesh. IDS Working Paper 8. Brighton: IDS.

Hart, S. L., \& Sharma, S. (2004). Engaging fringe stakeholders for competitive imagination. Prospective, 31(4), $7-18$.

Henry, S. (2006). Good practice in business development services: How do we enhance entrepreneurial skills in MFI clients? Toronto: Alterna Savings.

Hickey, S., \& Mohan, G. (2004). Relocating participation within a radical politics of development. London: Zed Books.

Hirschland, M. (Ed.) (2005). Savings services for the poor. Bloomfield, CT Kumarian Press Inc.

Hollis, A., \& Sweetman, A. (1998). Microcredit: What can we learn from the past? World Development, 26(10), 1875-1891. https://doi.org/10.1016/S0305-750X(98)00082-5

Hopwood, B., Mellor, M., \& O’Brien, G. (2005). Sustainable development: Mapping different approaches. Sustainable Development, 13(1), 38-52. https://doi.org/10.1002/sd.244

Isserles, R. G. (2003). Microcredit: The rhetoric of empowerment, the reality of "development as usual". Women's Studies Quarterly, 31(3/4), 38-57.

Karim, L. (2001). Politics of the poor? NGOs and grass-roots political mobilization in Bangladesh. Polar, 24(1), 92-107. https://doi.org/10.1525/pol.2001.24.1.92

Lairap-Fonderson, J. (2002). The disciplinary power of microcredit: Examples from Kenya and Cameron. World Development, 29(1), 63-84.

Mahamud, S. (2004). Micro-credit and women's empowerment. In S. Ahamed \& M. A. Hakim (Eds.), Bangladesh in attacking poverty with microcredit (pp. 96-124). Dhaka: Dhaka University Press.

Moore, M. H. (2000). Organizational strategy in for-profit, non-profit and governmental organizations. Nonprofit and Voluntary Sector, 29(1), 183-204. https://doi.org/10.1177/089976400773746391

Morduch, J. (1999). The microfinance promise. Journal of Economic Literature, 37, 1569-1614. https://doi.org/10.1257/jel.37.4.1569

Nordtveit, B. (2015). Producing literacy and civil society: The case of Senegal. Asia Pacific Education Review, 16(1), 1-11. https://doi.org/10.1007/s12564-015-9354-0

Patten, R., Rosengard, J., \& Johnston, D. (2001). Microfinance success amidst macroeconomic failure: The experience of Bank Rakyat Indonesia during the East Asia crisis. World Development, 29(6), 1057-1069. https://doi.org/10.1016/S0305-750X(01)00016-X

Prahalad, C. K. (2002). Strategies for the bottom of the pyramid. Reflections, 3(4), 1-22. https://doi.org/10.1162/152417302760127192

Quardir, F. (2003). How 'civil' is civil society? Authoritarian state partisan civil society and struggle for democratic development in Bangladesh. Canadian Journal of Development Studies, 24(3), 425-438. https://doi.org/10.1080/02255189.2003.9668930

Rahman, A. (1999). Micro-credit initiatives for equitable and sustainable development: Who pays? World Development, 27(1), 67-82. https://doi.org/10.1016/S0305-750X(98)00105-3

Report and Recommendations (2003). Prime minister's task force on women entrepreneurs. Ottawa: Prime 
Rouf, K. A.

Minister Office, Government of Canada.

Rosengard, J. K. (2001). Doing well by doing good: The future of microfinance via regulated financial institutions, Barcelona, Spain: III Inter-American forum on microfinance.

Rouf, K. A. (2011). Grameen Bank women borrowers' family space and public space development in Bangladesh. University of Toronto.

Schlefer, R., \& Stuart, G. (2005). Corporate values and transformation: The Microlender Compartamos. Harvard Kennedy School of Government Case.

Stuart, G. (2002). Women's thrift cooperatives in Andra Pradesh. Faculty Research Working Papers Series, John F. Kennedy School of Government, Harvard University.

Szulanski, G. (1996). Exploring internal stickiness: Impediments to the transfer of best practice within the firm, Strategic Management Journal, 17(S2), 27-43. https://doi.org/10.1002/smj.4250171105

Umar, B. (2001). Yunus's poverty trade. Dhaka: Bangladesh Lekhok Shibir.

Vogel, P., \& Burkett, R. C. (1986). Mobilizing small scale savings, approaches, costs and benefits. Industry and Finance Series, 15, 1-30.

White, V., \& Campion, A. (2002). Transformation: Journey from NGO to regulated MFI. In D. Drake \& E.

Rhyne (Eds.), Commercialization of microfinance (pp. 22-45). Bloomfield, CT.: Kumarian Press Inc.

Yunus, M. (2002). Grameen Bank-11: Designed to open new possibilities, Dhaka: Grameen Bank. 